\title{
The assessment of colostral immunity in dairy calves based on serum biochemical indicators and their relationships
}

\author{
Soňa Šlosárková ${ }^{1}$, Petr Fleischer ${ }^{1}$, Oldřich Pěnkava ${ }^{2}$, Miloslav Skřivánek ${ }^{1}$ \\ University of Veterinary and Pharmaceutical Sciences Brno, Faculty of Veterinary Medicine, ${ }^{1}$ Ruminant and \\ Swine Clinic, ${ }^{2}$ Department of Physiology, Brno, Czech Republic \\ Received November 29, 2013 \\ Accepted March 26, 2014
}

\begin{abstract}
Passive transfer of immunity in dairy calves is routinely monitored in North America. This study analyzes such type of biochemistry monitoring in 591 calves (Holstein, Fleckvieh) from 19 large farms in the Czech Republic. All calves, aged 1-6 days, were blood sampled once. Serum concentrations of total protein, albumin, zinc sulphate turbidity units and $\gamma$-glutamyltransferase activity were analysed by photometry methods. The samples were divided according to concentrations of total protein and zinc sulphate turbidity units, and the age of calves. These groups were compared using nonparametric tests. The samples had good mean values (total protein $63.5 \mathrm{~g} \cdot \mathrm{l}^{-1}$, albumin $30.5 \mathrm{~g} \cdot \mathrm{l}^{-1}$, zinc sulphate turbidity $11.5 \mathrm{U}, \gamma$-glutamyltransferase $10.7 \mu \mathrm{kat} \cdot \cdot^{-1}$ ) but $41 \%$ and $54 \%$ of calves had low total protein $\left(<60 \mathrm{~g} \cdot 1^{-1}\right)$ and zinc sulphate turbidity $(<12 \mathrm{U})$, respectively. The calves with low total protein showed markedly worse values in all indicators $(P<0.001)$. The groups according to zinc sulphate turbidity (thresholds 5, 10, $15 \mathrm{U})$ demonstrated gradual differences $(P<0.001)$ in all indicators except albumin. Only $\gamma$-glutamyltransferase showed very distinct age-sensitive differences; the highest activity was in 1-day-old calves $\left(18.3 \mu \mathrm{kat} \cdot \cdot^{-1}\right)$; calves aged 3-6 days had significantly lower activity. It is newly suggested that samples be taken from calves 1-3 days old for $\gamma$-glutamyltransferase analysis and traditionally anytime during the first week of life for all other indicators. This first extensive analysis of passive transfer in Central Europe shows that there are widespread deficiencies in the feeding of colostrum to calves.
\end{abstract}

Cattle, failure of passive transfer, total protein, zinc sulphate turbidity, immunoglobulins, $\gamma$-glutamyltransferase

In dairy herds where calves are administered colostrum by farm staff, the risk of human intervention failure is great. Frequently, calves born at night are not given colostrum early enough. However, the permeability of intestinal mucosa for immunoglobulins (Ig) dramatically decreases during the first hours of life (Godden 2008). Failure of passive transfer (FPT) of Ig results in increased morbidity and mortality of calves in the first weeks of life (Ibrahim and Lemma 2009); although in some cases increased morbidity was demonstrated for certain diseases only (Pithua and Aly 2013). Failure of passive transfer also affects the future prosperity of animals later in their lives, e.g. post-weaning growth performance (Donovan et al. 1998) or first parity milk yield (DeNise et al. 1989).

For these reasons it has been recommended for decades to test for passive transfer status by performing blood work in the calf (McGuirk 2011). The most apt description would be provided by a direct measurement of serum IgG levels. A direct check of colostral immunity is also provided by the estimation of Ig by zinc sulphate turbidity (ZST) test (Pavlata 2009). Indirect methods include the determination of serum total protein (TP) used worldwide, which is strongly positively correlated with the amount of circulating Ig (Parish et al. 1997; Weaver et al. 2000) and which can be measured by refractometer on farm. Gamma-glutamyl transferase (GGT) is transferred also from colostrum into the circulation. By measuring GGT it is possible to indirectly verify timely and proper administration of colostrum (Bertoni et al. 2009).

Address for correspondence:

MVDr. Petr Fleischer, Ph.D

Ruminant and Swine Clinic

Faculty of Veterinary Medicine

University of Veterinary and Pharmaceutical Sciences Brno

Palackého tř. 1/3, 61242 Brno, Czech Republic 
The aims of this study were to evaluate the level of colostral immunity in dairy calves in the Czech Republic as determined by routine blood examination, and to evaluate differences between the groups of samples divided according to the concentrations of $\mathrm{TP}$, Ig, and calf age at sampling as well as investigate the relationships between the indicators under study.

\section{Materials and Methods}

In this study, routine checks on calf colostrum feeding were undertaken between 2008 and 2011, and blood chemistry results were analysed. The samples were taken on 10 Holstein dairy farms and 9 Fleckvieh dairy farms. The average herd size was 392 (min. 146, max. 719) cows. The mean herd milk yield was 8,021 (min. 5,981, max. 9,951) kg milk. From each herd, on average 29 (min. 25, max. 41) samples (calves) were taken. Except for 2 farms, cows were loose-housed before calving in group and/or individual calving pens. Newborn calves were looked after from $04.00 \mathrm{~h}$ to $22.00 \mathrm{~h}$ on 12 farms, and for $24 \mathrm{~h}$ a day on the remaining 7 farms. On 18 farms, calves were immediately separated from their dam following parturition and given colostrum, mostly freshly milked but in some cases frozen colostrum.

In total 591 serum samples from calves aged 1-6 days were examined; the numbers of samples taken on the successive days of life were 96, 151, 110, 103, 77, and 54. Blood samples were withdrawn from the jugular vein by veterinary practitioners. After coagulation, serum was recovered without centrifugation and subsequently examined in our university laboratories. Serum concentrations of TP, albumin (Alb), and GGT were analysed by photometry methods, using the device DPC Konelab 20i (Thermo scientific), by means of standard diagnostic sets

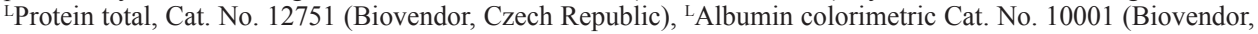
Czech Republic), ${ }^{\mathrm{L}}$ Gammaglutamyl transferase, Cat. No. 11502 (Biovendor, Czech Republic). The passive transfer status was also assessed using the ZST test modified by Slanina et al. (1976). Globulins (Glb) were calculated from TP and Alb.

The samples were grouped according to: 1) concentration of TP (TP $<$ resp. $\left.\geq 60 \mathrm{~g} \cdot \mathrm{l}^{-1}\right)$, 2) concentration of ZST units (U) ( $<5 \mathrm{ZST} \mathrm{U}, \geq 5$ and $<10 \mathrm{ZST} \mathrm{U}, \geq 10$ and $<15 \mathrm{ZST} \mathrm{U}, \geq 15 \mathrm{ZST} \mathrm{U})$ and 3$)$ the age of calf at sampling. For each group, mean values and standard deviations were calculated. The groups were compared using MannWhitney test in case of 2 groups and Kruskal-Wallis test in case of more than 2 groups. Relationships between the indicators were assessed by linear correlation. The statistic processing of the data was performed by KyPlot (v. 2.0 beta 15 , Koichi Yoshioka, Japan). $P$ value of $<0.05$ was considered significant.

\section{Results}

Mean serum concentrations of TP, Alb, Glb, Ig estimated by ZST and GGT activity in calves aged 1-6 days are given in Table 1. Recommended values are also listed, used as indicators of calf colostral nutrition quality (Pavlata 2009).

Table 2 presents results grouped according to TP concentrations. The chosen TP threshold $\left(\geq 60 \mathrm{~g} \cdot \mathrm{l}^{-1}\right)$ was not achieved by $41 \%$ of calves and highly significant differences were found between the samples grouped by TP in all studied variables.

Concentrations of all serum indicators measured in calves aged 1-6 days divided into 4 groups according to ZST are listed in Table 3. Values of ZST $\geq 15 \mathrm{U}$ were found in $28 \%$

Table 1. Basic statistical characteristics and reference values of serum biochemical indicators relating to passive transfer status in calves aged $1-6$ days $(\mathrm{n}=591)$

\begin{tabular}{lccccc}
\hline & Total protein & Albumin & Globulins & $\begin{array}{c}\text { Ig estimated } \\
\text { by ZST }\end{array}$ & $\begin{array}{c}\gamma \text {-glutamyl } \\
\text { transferase }\end{array}$ \\
\hline & $\mathrm{g} \cdot 1^{-1}$ & $\mathrm{~g} \cdot \mathrm{l}^{-1}$ & $\mathrm{~g} \cdot \mathrm{l}^{-1}$ & $\mathrm{U}$ & $\mu \mathrm{kat} \cdot \mathrm{l}^{-1}$ \\
\hline Mean & 63.5 & 30.5 & 32.9 & 11.5 & 10.7 \\
S.D. & 12.5 & 4.1 & 11.1 & 6.4 & 11.3 \\
Min. & 30.6 & 20.7 & 8.7 & 0.3 & 0.2 \\
Max. & 90.7 & 41.8 & 56.4 & 30.8 & 57.7 \\
\hline Recommended $^{1}$ & $>60$ & $>28$ & $>30$ & $>12$ & $>10$ \\
\hline
\end{tabular}

Ig - immunoglobulins, ZST - zinc sulphate turbidity, ${ }^{1}$ Pavlata (2009) 
Table 2. Biochemistry indicators of calves aged 1-6 days grouped according to total protein concentration ( $\mathrm{x} \pm$ S.D.)

\begin{tabular}{|c|c|c|c|c|c|c|c|}
\hline $\begin{array}{l}\text { Concentration } \\
\text { of TP }\end{array}$ & \multicolumn{2}{|c|}{ Calves } & $\mathrm{TP}$ & Albumin & Globulins & Ig by ZST & $\begin{array}{l}\gamma \text {-glutamyl } \\
\text { transferase }\end{array}$ \\
\hline $\mathrm{g} \cdot 1^{-1}$ & $\mathrm{n}$ & $\%$ & $\mathrm{~g} \cdot \mathrm{l}^{-1}$ & $\mathrm{~g} \cdot 1^{-1}$ & $\mathrm{~g} \cdot 1^{-1}$ & $\mathrm{U}$ & $\mu \mathrm{kat} \cdot \mathrm{l}^{-1}$ \\
\hline$<60$ & 240 & 41 & $51.7 \pm 5.8$ & $28.4 \pm 3.9$ & $20.2 \pm 4.0$ & $5.5 \pm 4.2$ & $4.8 \pm 7.7$ \\
\hline$\geq 60$ & 351 & 59 & $71.5 \pm 9.0$ & $31.3 \pm 3.9$ & $37.5 \pm 9.6$ & $13.7 \pm 5.6$ & $13.2 \pm 11.6$ \\
\hline$P$ & & & $* * *$ & $* * *$ & $* * *$ & $* * *$ & $* * *$ \\
\hline
\end{tabular}

$\mathrm{TP}$ - total protein, Ig - immunoglobulins, ZST - zinc sulphate turbidity, ${ }^{* * *} P<0.001$

of calves, and the 2 groups with the lowest ZST values (ZST $<10 \mathrm{U})$ comprised $43 \%$ of calves. Fifty-four percent of calves were classified as having unacceptable passive transfer status when a cut-off level for ZST of $12 \mathrm{U}$ was used. According to ZST in all 4 groups gradually increasing concentrations were observed in all the indicators under study except for Alb.

The values measured in groups by age at the sampling are given in Table 4; significant differences were found only in GGT and Alb. Alb values at 3, 5 and 6 days of age were only slightly higher compared with those measured at 1 and 2 days of age. Of all the variables under study, GGT activity showed the greatest differences between days of age; its highest mean values were measured at 1 day of age, whereas at 3 and more days of age, GGT activity values were significantly lower. Relationships were demonstrated by linear correlation between the values of studied indicators. Alb showed only moderate variability

Table 3. Biochemistry indicators of calves aged 1-6 days according to immunoglobulin concentrations estimated by zinc sulphate turbidity $(x \pm$ S.D.)

\begin{tabular}{lccccccc}
\hline $\begin{array}{l}\text { Concentration } \\
\text { of ZST }\end{array}$ & Calves & Ig by ZST & Total protein & Albumin & Globulins & $\begin{array}{l}\gamma \text {-glutamyl } \\
\text { transferase }\end{array}$ \\
\hline $\mathrm{U}$ & $\mathrm{n}$ & $\%$ & $\mathrm{U}$ & $\mathrm{g} \cdot \mathrm{l}^{-1}$ & $\mathrm{~g} \cdot \mathrm{l}^{-1}$ & $\mathrm{~g} \cdot \mathrm{l}^{-1}$ & $\mu \mathrm{kat} \cdot \mathrm{l}^{-1}$ \\
\hline$<5$ & 109 & 18 & $2.4 \pm 1.2$ & $48.2 \pm 6.4$ & $29.1 \pm 4.5$ & $19.6 \pm 4.7$ & $2.4 \pm 4.1$ \\
$\geq 5$ and $<10$ & 144 & 25 & $7.9 \pm 1.4$ & $59.3 \pm 8.4$ & $30.9 \pm 4.1$ & $28.5 \pm 6.6$ & $7.5 \pm 8.0$ \\
$\geq 10$ and $<15$ & 170 & 29 & $12.5 \pm 1.3$ & $64.6 \pm 8.5$ & $30.6 \pm 3.6$ & $34.0 \pm 7.7$ & $11.5 \pm 9.8$ \\
$\geq 15$ & 168 & 28 & $19.4 \pm 3.8$ & $74.9 \pm 10.8$ & $30.7 \pm 3.6$ & $44.2 \pm 10.4$ & $18.0 \pm 13.3$ \\
\hline $\mathrm{P}$ & & & $* * *$ & $* * *$ & $*$ & $* * *$ & $* * *$ \\
\hline
\end{tabular}

Ig - immunoglobulins, ZST - zinc sulphate turbidity, ${ }^{* * *} P<0.001 ;{ }^{*} P<0.05$

Table 4. Biochemistry indicators of calves aged 1-6 days in blood serum according to age ( $\mathrm{x} \pm$ S.D.)

\begin{tabular}{lcccccc}
\hline Age & $\mathrm{n}$ & Total protein & Albumin & \multicolumn{2}{c}{ Globulins } & \multicolumn{2}{c}{ Ig by ZST $\gamma$-glutamyl transferase } \\
\hline Days & & $\mathrm{g} \cdot \mathrm{l}^{-1}$ & $\mathrm{~g} \cdot \mathrm{l}^{-1}$ & $\mathrm{~g} \cdot 1^{-1}$ & $\mathrm{U}$ & $\mu \mathrm{kat} \cdot 1^{-1}$ \\
\hline 1 & 96 & $61.5 \pm 13.0$ & $29.9 \pm 4.6^{\mathrm{a}}$ & $31.7 \pm 11.1$ & $10.8 \pm 6.0$ & $18.3 \pm 15.4^{\mathrm{e}, \mathrm{f}, \mathrm{g}, \mathrm{h}}$ \\
2 & 151 & $64.8 \pm 12.7$ & $29.7 \pm 3.7^{\mathrm{b}, \mathrm{c}, \mathrm{d}}$ & $35.1 \pm 12.0$ & $12.2 \pm 6.9$ & $13.0 \pm 11.0^{\mathrm{i}, \mathrm{j}}$ \\
3 & 110 & $63.8 \pm 11.3$ & $31.1 \pm 3.9^{\mathrm{b}}$ & $32.5 \pm 10.3$ & $10.8 \pm 5.8$ & $9.0 \pm 8.6^{\mathrm{e}, \mathrm{k}}$ \\
4 & 103 & $62.7 \pm 9.6$ & $30.7 \pm 3.4$ & $32.0 \pm 8.9$ & $11.3 \pm 5.2$ & $7.3 \pm 5.4^{\mathrm{f}, \mathrm{l}}$ \\
5 & 77 & $64.5 \pm 12.4$ & $31.7 \pm 3.6^{\mathrm{a}, \mathrm{d}}$ & $32.7 \pm 11.5$ & $12.1 \pm 6.5$ & $6.3 \pm 7.0^{\mathrm{g}, \mathrm{i}}$ \\
6 & 54 & $61.8 \pm 13.6$ & $31.5 \pm 3.3^{\mathrm{c}}$ & $30.4 \pm 12.8$ & $11.2 \pm 6.7$ & $4.5 \pm 4.0^{\mathrm{h}, \mathrm{j}, \mathrm{k}, \mathrm{l}}$ \\
\hline
\end{tabular}

aa, bb, ii, kk, ll, $P<0.05$; ${ }^{\text {cc }} P<0.01$; dd, ee, ff, gg, hh, ,j $P<0.001$ 
and medium positive correlation with TP $(\mathrm{r}=0.40 ; P<0.001)$ and weak correlation with $\operatorname{Ig}(\mathrm{r}=0.12 ; P<0.01)$. A very strong positive correlation was found between $\mathrm{TP}$ and Glb $(\mathrm{r}=0.95 ; P<0.001)$. Ig values showed a relatively strong positive correlation with $\mathrm{TP}$, or Glb $(\mathrm{r}=0.77$, resp. $0.79 ; P<0.001)$. GGT showed a medium positive correlation with $\mathrm{Ig}$, $\mathrm{TP}$, or Glb (r=0.51, 0.48 resp. $0.55 ; P<0.001)$.

\section{Discussion}

The mean values of the studied indicators (Table 1) can be regarded as favourable not only because they correspond (with a slight deviation in ZST) with the recommended values (Pavlata 2009), but also because a previous less extensive study (Podhorský et al. 2007) found markedly lower values (TP $53.6 \mathrm{~g} \cdot \mathrm{l}^{-1}$; Alb $30.0 \mathrm{~g} \cdot \mathrm{l}^{-1}$; Glb $23.6 \mathrm{~g} \cdot \mathrm{l}^{-1}$; Ig 8.20 U ZST; GGT $8.95 \mu \mathrm{kat}^{\cdot l^{-1}}$ ). It can be explained by the fact that the present study included mainly progressive large farms that were aware of the importance of colostral nutrition and performed routine checks of the calves' immune status, using the results for herd management. On the contrary, Podhorský et al. (2007) studied herds with varying levels of management, including poor ones whose calf management was not based on the knowledge of passive transfer status in their neonatal calves.

In order to better assess the level of passive transfer status, the analysis results were grouped according to TP concentrations (Table 2) and ZST U reflecting serum Ig concentrations (Table 3). The TP cut-point levels used abroad are 50, 52 and, most commonly, $55 \mathrm{~g} \cdot \mathrm{l}^{-1}$; however, those are TP values derived from serum total solids measured by refractometer (Weaver et al. 2000; Godden 2008). We chose a higher cut-point of $60 \mathrm{~g} \cdot \mathrm{l}^{-1}$ which corresponds with the values recommended for the Czech conditions (Pavlata 2009), and, above all, is based on laboratory photometric TP measurements. This approach is in accordance with the previous findings that refractometric values are slightly lower than those measured by photometry (Kraft and Dürr 2001). Markedly lower Ig concentrations estimated by ZST and lower GGT activity in serum of the calves with TP under $60 \mathrm{~g} \cdot \mathrm{l}^{-1}$ indicate substantially poorer colostral immunity.

Values of ZST $\geq 15 \mathrm{U}$, achieved by only $28 \%$ of calves included in this study, were also used by Fallon (1978) as an indicator of sufficient colostrum supply to the calf. Values $\geq 15 \mathrm{U}$ ZST can be regarded as the target; however, with regard to TP concentrations this threshold may appear relatively strict. With respect to TP, ZST values over $10 \mathrm{U}$ could be considered acceptable in this study, or corresponding with $12.5 \mathrm{U}$ which is a mean of the range $\geq 10$ and $<15 \mathrm{ZST} \mathrm{U}$, for which mean TP value measured was $64.6 \mathrm{~g} \cdot \mathrm{l}^{-1}$. This is in accordance with the recommended values for the Czech Republic, i.e. calves should have over 12 U ZST (Pavlata 2009). Also in the calves with ZST between $\geq 5$ and $<10$ ZST $\mathrm{U}$ mean TP concentration was almost $60 \mathrm{~g} \cdot \mathrm{l}^{-1}\left(59.3 \mathrm{~g} \cdot \mathrm{l}^{-1}\right)$; however, in that group mean values of serum globulin and GGT activity were markedly lower that the concentrations recommended by Pavlata (2009).

Similar trends in GGT values, being highest on the first or second day of life were reported by Braun et al. (1982) and Bertoni et al. (2009), which is probably due to a short halftime of this enzyme. On the contrary, TP and IgG concentrations decrease after the peak by approximately $0.7 \mathrm{~g} \cdot \mathrm{l}^{-1}$ of TP and $0.74 \mathrm{~g} \cdot \mathrm{l}^{-1}$ of IgG per day only (Villarroel et al. 2013). This implies that colostral immunity checks of calves can be performed during the first week of life. More accurately, Godden (2008) recommended taking blood samples between $24 \mathrm{~h}$ and 7 days after birth because in calves the values of studied indicators except for GGT, are relatively stable early in life. When using GGT as a marker of colostrum provision, we recommend taking samples at 1-3 days of age because it is more difficult to interpret these values in older calves.

Albumin which showed the fewest associations with the other indicators in this study, 
shows a relatively stable serum concentration (Bertoni et al. 2009), and therefore alone it is of no importance for colostral immunity testing.

Similar associations between ZST U and TP, or Glb $(r=0.79$, and 0.82 , respectively) were also found by Pavlata et al. (2005). A strong correlation $(\mathrm{r}=0.71)$ was found also by Murphy et al. (2005) between Ig estimated by ZST and IgG1 (measured by radial immunodiffusion). Those researches therefore considered ZST test a good indicator of the calf immune status, which is faster and cheaper than IgG1 determination. On the contrary, Weaver et al. (2000) pointed out the drawbacks of original ZST, particularly the low sensitivity of the test, risk of results being distorted by occasional haemolysis and degradation of reaction solution when exposed to atmospheric $\mathrm{CO}_{2}$. However, modification of ZST according to Slanina et al. (1976) eliminates the latter influencing factors. In the Czech Republic, direct methods of routine testing of success of a dairy herd's colostrum management program are based on ZST because the golden standard, i.e. direct measurement of IgG1 concentration, is not used for routine purposes as it is expensive and time-consuming; which is also the case in the USA (McGuirk 2011).

GGT can be used as an indicator of colostral immunoglobulin transfer, but because of great variability it should be used to assess passive transfer status in groups of calves. This is in accordance with findings of other researchers suggesting GGT as an indicator of the amount of colostrum ingested which, however, only roughly reflects colostrum quality (Braun et al. 1982). Parish et al. (1997) concluded that GGT is a good indicator for assessing the amount of circulating IgG1 provided that the age of calf is taken into account. They consider the values of 3.34 and $1.66 \mu \mathrm{kat} \cdot \mathrm{l}^{-1}$ as a minimum for calves at 3 and 4-6 days of age, respectively. However, the above values are rather low because, like our findings, Güngör et al. (2004) found a markedly higher concentration of $17.45 \mu \mathrm{kat} \cdot \mathrm{l}^{-1}$ in one-day-old calves with optimum passive transfer. In order to decide whether a calf received some colostrum, even markedly lower values are sufficient because before receiving a colostrum meal newborn calves show nearly zero GGT activity (Braun et al. 1982). An advantage of GGT as a marker is its low dependence on hydration of the body, unlike TP values. If a calf is dehydrated at the time of blood sampling, TP values measured are falsely increased, but GGT activity is not greatly influenced (Parish et al. 1997).

This first extensive analysis of passive transfer in Central Europe shows that there are widespread deficiencies in the feeding of colostrum to calves. Farms should innovate their colostrum feeding routines and above all, ensure consistency according to the recommendations published by Godden (2008) and McGuirk (2011).

\section{Acknowledgement}

This study was supported by Ministry of Agriculture of the Czech Republic by grant NAZV QI91A238.

\section{References}

Bertoni G, Ferrari A, Gubbiotti A, Trevisi E 2009: Blood indices calves: relationship with mother values and changes in the first days of life. Ital J Anim Sci (Suppl 2) 8: 595-597

Braun JP, Tainturier D, Laugier C, Bénard P, Thouvenot JP, Rico AG 1982: Early variations of blood plasma gamma-glutamyl transferase in newborn calves - a test of colostrum intake. J Dairy Sci 65: 2178-2181

DeNise SK, Robison JD, Stott GH, Armstrong DV 1989: Effects of passive immunity on subsequent production in dairy heifers. J Dairy Sci 72: 552-554

Donovan GA, Dohoo IR, Montgomery DM, Bennett FL 1998: Associations between passive immunity and morbidity and mortality in dairy heifers in Florida, USA. Prev Vet Med 34: 31-46

Fallon RJ 1978: The effect of immunoglobulin levels on calf performance and methods of artificially feeding colostrum to the new born calf. Ann Rech Vet 9: 347-352

Godden S 2008: Colostrum management for dairy calves. Vet Clin Food Anim 24: 19-39

Güngör Ö, Bastan A, Erbil MK 2004: The usefulness of the $\gamma$-glutamyltransferase activity and total proteinemia in serum for detection of the failure of immune passive transfer in neonatal calves. Revue Méd Vét 155: 27-30 
Ibrahim A, Lemma A 2009: Relationships between serum protein concentration and passive transfer of immunity, morbidity and mortality of dairy calves in market oriented urban dairy farms. Revue de Méd Vét 180: 394-399

Kraft W, Dürr U 2001: Clinical Laboratory Diagnostics in Veterinary Medicine (in Slovak). H\&H, Bratislava, $380 \mathrm{p}$.

McGuirk S 2011: Management of Dairy Calves from Birth to Weaning. In: Risco CA, Melendez P (Eds): Dairy Production Medicine. Wiley-Blackwell, West Sussex, UK, pp. 175-193

Murphy BM, Drennan MJ, O’Mara EP, Early B 2005: Cow serum and colostrum immunoglobulin (IgG1) concentration of five suckler cow breed types and subsequent status of their calves. Irish J Agr Food Res 44: 205-213

Parish SM, Tyler JW, Besser TE, Gay CC, Krytenberg D 1997: Prediction of serum IgG1 concentration in Holstein calves using serum gamma glutamyltransferase activity. J Vet Intern Med 11: 344-347

Pavlata L 2009: Relationship mother-young (in Czech). In: Hofírek B, Dvořák R, Němeček L, Doležel R, Pospíšil Z (Eds): Diseases of Cattle (in Czech). Česká buiatrická společnost, Brno, pp. 954-957

Pavlata L, Podhorský A, Pechová A, Dvořák R 2005: Metabolic disorders of calves in postpartum period. In: Malinowski E, Bednarek D (Eds): Achievements and Prospects of Ruminants Medicine. Polish Association for Buiatrics, Pulawy, pp. 125-130

Pithua P, Aly SS 2013: A cohort study of the association between serum immunoglobulin G concentration and preweaning health, growth, and survival in Holstein calves. Int J Appl Res Vet M 11: 77-84

Podhorský A, Dvořák R, Pechová A, Pavlata L 2007: Metabolic disorders in dairy calves in postpartum period. Acta Vet Brno 76: 45-53

Slanina L, Vajda V, Blažej J 1976: Turbidimetric analysis of immunoglobulins in calves and their clinical evaluation (in Slovak). Veterinářství 16: 392-394

Villarroel A, Miller TB, Johnson ED, Noyes KR, Ward JK 2013: Factors affecting serum total protein and immunoglobulin $\mathrm{G}$ concentration in replacement dairy calves. Adv Dairy Res 1: 106

Weaver DM, Tyler JW, VanMetre DC, Hostetler DE, Barrington GM 2000: Passive transport of colostral immunoglobulins in calves. J Vet Intern Med 14: 569-577 